\title{
Funds of Knowledge: An examination of theoretical frameworks
}

\section{LINDA HOGG}

\section{Abstract}

This review of funds of knowledge (FoK) literature relating to school settings analysed the conceptual bases reported in fifty texts. Findings reveal diverse theoretical frameworks, including socio-cultural learning theory, critical theory, hybridity theory, systems theory, and the difference theory of caring. Findings regarding links between key theories and the FoK concept are presented. The paper relates FoK work to social justice issues in New Zealand schooling, and discusses issues arising from the diverse theoretical frameworks within which FoK work is situated. Identification of theoretical frameworks is recommended to enhance richness, depth of thinking, and opportunities for transformation in future discourse.

\section{Background}

ocial justice issues in schooling are the subject of government policy initiatives internationally, such as the No Child Left Behind (NCLB) Act in the United States (U. S. Department of Education, 2001), the Every Child Matters: Change for Children policy in the United Kingdom (DfES, 2004), and Ka Hikitia in New Zealand (Ministry of Education, 2009). These policy initiatives aim to address the pervasive issues of academic achievement differences across ethnic groups (Archer \& Francis, 2007; NZQA, 2010; U.S. Department of Education, National Center for Education Statistics, 2003), and differences in experiences of schooling across ethnic groups (Bishop, Berryman, Tiakiwai, \& Richardson, 2003; Gregory, Skiba, \& Noguera, 2010; KewelRamani, Gilbertson, Fox, \& Provasnik, 2007; Ministry of Education, 2005, 2007; Wallace, Goodkind, Wallace, \& Backman, 2008). 
A key question in this important work is why do achievement gaps between ethnic groups exist? Various paradigms offer different explanations of this issue (Banks \& Park, 2010). The arguments of deficit theorists, rooted in "early racist discourse" (Menchaca, 1997, p. 13), have historically evolved to match the prevailing philosophy of the time, moving from blaming the poor genetics of the student, to the student's culture and class, to his/her family, home environment and social capital (Banks \& Park, 2010; Lee, 2009; Valencia, 2010). This process of adaptation supports the continued prevalence of deficit theorising. Bishop (2005) argues that in New Zealand, deficit thinking has become an entrenched mindset as a result of the dominant colonialist discourse. By this, Bishop means that deficit thinking is intricately linked with prevailing notions of schools as a tool of power and control with a missionary civilising role, to redress perceived inferiority in the behaviours of the indigenous population. Bishop et al. (2003) report that in mainstream New Zealand secondary schools, deficit theorising remains the dominant teacher discourse; they also found that many teachers expressed frustration regarding Māori students' low achievement levels. This seems to suggest that teachers may simultaneously hold a desire to support Māori students, and be held back by their own deficit thinking. Unhelpfully, deficit theorising often co-exists with low teacher expectations and a lack of teacher self-efficacy so that, as Penetito (2001) explains "far too many of our schools and their teachers simply do not engage Māori children or more bluntly, do not teach Māori children” (p. 17).

The funds of knowledge (FoK) concept presents a framework which allows an alternative perspective of ethnic minority students. Banks and Park (2010) locate the FoK concept within the cultural difference paradigm, which situates the problem of the achievement gap with schools, thus perceiving the achievement gap as best addressed with culturally responsive teaching. Therefore, this paradigm "challenge(s) the prevailing assumption that it is only students from marginalized groups and their families ... who should always conform in order to be successful at school... teachers and schools also need to change" (Nieto, 2010, p. 101). In contrast with 
New Zealand teachers' dominant discourses (Bishop, 2005), proponents of the cultural difference paradigm see teachers as agentic.

In New Zealand, mainstream schools reflect Pākehā cultural values (Penetito, 2002), contributing to the risk of marginalisation of students and families from other groups. This risk is reinforced by findings from Biddulph, Biddulph, and Biddulph's (2003) best evidence synthesis that in the absence of significant contextualisation of learning, for Maori or Pasifika students, ethnicity and culture have negative impacts on achievement. The New Zealand teaching profession is predominantly Pākehā, suggesting the need for teachers to develop cultural sensitivity and knowledge (Walker, 1973). However, unlike their colleagues from minoritised groups, Pākehā teachers are more likely to believe that students should all be treated as if they were the same (McFarlane, Glynn, Grace, Penetito, \& Bateman, 2008). Because the funds of knowledge concept highlights the value of teachers knowing students "culturally (which) is not the same as knowing (them) psychologically” (Penetito, 2001, p. 20), this lens may support teachers to reflect on schools as implications of cultural disconnection between teachers and students, and develop a more culturally responsive approach to classroom practice.

\section{Funds of knowledge}

Definitions of the FoK concept are divergent (Hogg, 2011), including bodies of knowledge which are strategically important for household functioning (Moll \& Greenberg, 1990) and for wellbeing of individuals (Moll, Amanti, Neff, \& Gonzalez, 1992), areas of knowledge from life experiences (Gonzalez \& Moll, 2002) including “dark" knowledge (Zipin, 2009) and pedagogies which operate within households (Zipin, 2009). FoK have also been discussed as sources of knowledge from life experiences (Moje et al., 2004). Scholarly work in the field also applies different views related to who holds FoK, including household members (such as Andrews \& Yee, 2006; Moll \& Greenberg, 1990), teachers (such as Hughes \& Pollard, 2006), students (such as Basu \& Barton, 2007; Moje et al., 2004), and adults (such as Civil \& Bernier, 2006; Hammond, 2001). 
Despite differences in definitions of the term, throughout its history, the concept of FoK has been presented as a framework for identifying and acknowledging the considerable prior knowledge of students (see, for example, Moje et al., 2004; Moll, 1992), with a particular focus on Latino and other low income students of colour who are marginalised in schools. The concept of FoK therefore challenges popular deficit theorising models, addressing social justice issues expressed by Spindler and Spindler (1983) as "the intense brutality of a system that does not really seem to 'see' children" (p. 75).

\section{Literature review purpose}

This review seeks to investigate how FoK scholars who locate their research in school settings theorise their work, with the aim of enriching discussion about the transformative possibilities of application of the FoK concept for ethnic minority students. Given the pervasiveness of deficit theorising of ethnic minority students, both a compelling evidence base and convincing conceptual framework for an alternative model become especially important, if the FoK concept is to be successful in supporting transformation of thinking and practice in education. As for the phenomenon of over-representation of ethnic minorities in special education, as Artiles, Klingner, and Tate (2006) state "one of the most basic and contentious issues ... is how we theorize the phenomenon” (p. 4).

Analysis of position papers and research in the field reveals that scholars identify FoK work as being underpinned by a variety of theoretical frameworks. This review describes the range of theoretical frameworks drawn on, explaining how the work of cited theorists is linked to the FoK concept. It also examines these for coherence, and explores the implications of various theoretical approaches to the FoK concept, its application in teaching practice, and relevance for teacher education.

\section{Methodology and limitations}

This paper reports on findings from a review of FoK research conducted in school settings and position papers relating to the 
application of FoK within school settings. Texts were located using a range of electronic databases available to me: Scopus, Educational Resources Information Centre (ERIC), A+ Education, Proquest, Index New Zealand, and World Cat, as well as by manual search of the (institution) catalogue. This review draws on my reading of 50 texts in the field, including 37 journal articles, 11 book chapters and two government reports. These texts formed the material for a comparative analysis which I undertook using a grid template.

As noted above, the literature search was limited to papers that described findings of research conducted in school settings only, excluding other educational settings such as early childhood centres and tertiary institutions. The search was also limited to articles published in English, which affected findings regarding the limited geographic scope of studies. Lastly, the review was confined to texts which used the term funds of knowledge, thus locating the work by name within this field.

\section{Findings: Theorists and theoretical frameworks cited by Funds of Knowledge scholars}

This section of the review begins by describing an overview of the range of conceptual bases identified by writers in the field. I then present descriptions of key theorists' ideas as related to the FoK concept. The section is followed by discussion of issues arising from variations.

\section{Overview}

Of the 50 texts reviewed, 28 included descriptions of the conceptual basis of the work. These bases encompassed a range of theoretical frameworks, with two main areas of theories showing the most popularity. As shown in Figure 1, 22 of the 50 texts reviewed identified the conceptual basis of FoK as socio-cultural learning theories, and 25 of the 50 texts related the work to critical theory. Twelve situated the work within both these conceptual frameworks, making these the most popular conceptual bases for the field. 


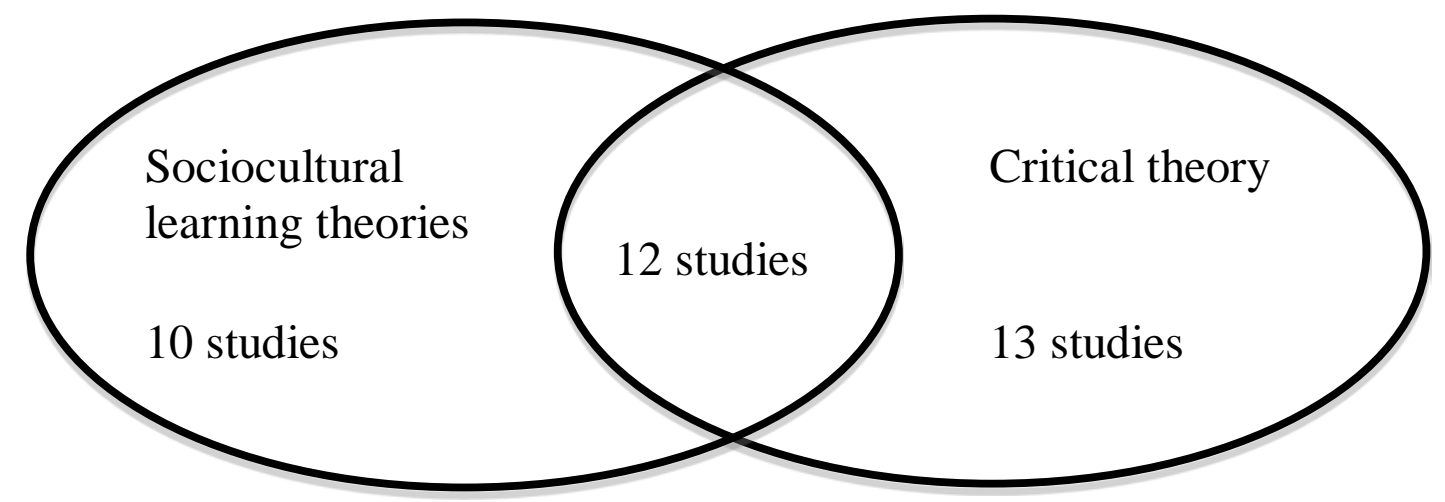

Figure 1: Conceptual bases identified for funds of knowledge research

A degree of divergent thinking relating to the theoretical basis of the concept is evident and to be expected given differences in approach to the FoK definition described earlier. Differences also result from variation in the particular area of education scholarship to which writers have applied the concept. Other theoretical bases identified were hybridity theory, systems theory, and difference theory of caring. Table 1 provides a summary of the range of theoretical frameworks and theorists cited.

Table 1: Theoretical frameworks presented for Funds of Knowledge

\begin{tabular}{|c|c|c|c|}
\hline Theoretical & \multicolumn{3}{|c|}{ Research examples of each (in chronological order) } \\
\hline \multirow[t]{2}{*}{$\begin{array}{l}\text { Socio-cultural } \\
\text { theories of } \\
\text { learning }\end{array}$} & $\begin{array}{l}\text { Vygotsky: } \\
\text { Moll \& Greenberg, } 1990 \\
\text { Moll, Velez-Ibanez et al., } \\
1990 \\
\text { Moll, } 1992 \\
\text { Gonzalez, Andrade, Civil, } \\
\text { \& Moll, } 2001\end{array}$ & $\begin{array}{l}\text { Gonzalez et al., } 2001 \\
\text { Rosebery, McIntyre, \& } \\
\text { Gonzalez, } 2001 \\
\text { Lee, } 2001 \\
\text { Gonzalez \& Moll, } 2002\end{array}$ & $\begin{array}{l}\text { Moje, et al., } 2004 \\
\text { Gonzalez, Moll, \& } \\
\text { Amanti, 2005 } \\
\text { Varelas \& Pappas, } 2006 \\
\text { Irizarry, 2009 } \\
\text { Smythe \& Toohey, } 2009\end{array}$ \\
\hline & $\begin{array}{l}\text { Lave and Wenger: } \\
\text { Lee, } 1998 \\
\text { Lee, } 2001 \\
\text { Bouillion \& Gomez, } 2001 \\
\text { Gonzalez et al., } 2001\end{array}$ & $\begin{array}{l}\text { Gonzalez \& Moll, } 2002 \\
\text { Upadhyay, } 2005 \\
\text { Hughes \& Greenhough, } \\
2006\end{array}$ & $\begin{array}{l}\text { Barton and Tan, } 2009 \\
\text { Fitts, } 2009 \\
\text { Smythe \& Toohey, } 2009\end{array}$ \\
\hline \multirow[t]{2}{*}{ Critical theory } & $\begin{array}{l}\text { Giroux: } \\
\text { Moll et al., } 1990 \\
\text { Gonzalez et al., } 1995 \\
\text { Bouillion \& Gomez, } 2001\end{array}$ & $\begin{array}{l}\text { Gonzalez \& Moll } 2002 \\
\text { Olmedo, } 2004 \\
\text { Gonzalez, } 2005\end{array}$ & $\begin{array}{l}\text { Hattam, Brennan, Zipin, } \\
\text { \& Comber, } 2009 \\
\text { Upadhyay, } 2009\end{array}$ \\
\hline & $\begin{array}{l}\text { Freire: } \\
\text { Gonzalez et al., } 1995 \\
\text { Gonzalez, } 2005\end{array}$ & $\begin{array}{ll}\text { Antrop-Gonzalez \& } & \text { De } \\
\text { Jesus, 2006 } & \\
\text { Basu \& Barton, 2007 } & \end{array}$ & $\begin{array}{l}\text { Hattam \& Prosser, } 2008 \\
\text { Irizarry, } 2009 \\
\text { Hattam et al., } 2009\end{array}$ \\
\hline
\end{tabular}




\begin{tabular}{llll}
\hline \multicolumn{1}{c}{$\begin{array}{c}\text { Theoretical } \\
\text { basis }\end{array}$} & \multicolumn{3}{c}{ Research examples of each (in chronological order) } \\
\hline $\begin{array}{l}\text { Critical theory } \\
\text { (contd.) }\end{array}$ & $\begin{array}{l}\text { Bourdieu: } \\
\text { Gonzalez et al., 2001 } \\
\text { Lee, 2001 } \\
\text { Gonzalez \& Moll, 2002 } \\
\text { Moje et al., 2004 }\end{array}$ & $\begin{array}{l}\text { Upadhyay, 2005 } \\
\text { Gonzalez et al., 2005 } \\
\text { Varelas \& Pappas, 2006 } \\
\text { Zipin, 2009 } \\
\text { Klenowski, 2009 }\end{array}$ & $\begin{array}{l}\text { Smythe \& Toohey, 2009 } \\
\text { Barton \& Tan, 2009 } \\
\text { Irizarry, 2009 } \\
\text { Hattam et al., 2009 }\end{array}$ \\
\cline { 2 - 4 } & $\begin{array}{l}\text { Foucault: } \\
\text { Gonzalez et al., 1995 }\end{array}$ & Gonzalez et al., 2001 & Irizarry, 2009 \\
\hline $\begin{array}{l}\text { Hybridity } \\
\text { theory }\end{array}$ & $\begin{array}{l}\text { Moje et al., 2004 } \\
\text { Varelas \& Pappas, 2006 }\end{array}$ & Barton \& Tan, 2009 & Fitts, 2009 \\
\hline $\begin{array}{l}\text { Systems theory } \\
\text { Patterson \& Baldwin, }\end{array}$ & 2001 & & \\
\hline $\begin{array}{l}\text { Difference } \\
\text { theory of } \\
\text { caring }\end{array}$ & Antrop-Gonzalez \& & & \\
\hline
\end{tabular}

\section{Socio-cultural theories of learning}

The foundation work in the field - by education and anthropology academics such as Carlos Velez-Ibanez, James Greenberg, Luis Moll, Norma Gonzalez, and others, based in Tucson, Arizona, USA combines the interests of educational anthropology, concerned with interactional dynamics in classrooms, and socio-cultural psychology, bringing a Vygotskian interest to the key role of social interactions in learning (Moll et al., 1990). Unsurprisingly, their work places FoK conceptualisation solidly within the framework of Vygotsky's (1978) theory of learning as a socio-cultural process. A large proportion of others in the field also ground the concept in socio-cultural learning theory, citing works by Vygotsky, as well as Lave and Wenger.

\section{Vygotsky}

Vygotsky's theories provide the conceptual basis for thirteen of the reviewed studies. Socio-cultural learning theory states that context and setting are key factors for understanding human thinking (Moll \& Greenberg, 1990), since learning results from social interaction between individuals, society and culture (Rogoff, 1990; Tharp \& Gallimore, 1993, both cited in Rosebery et al., 2001). Thus, understanding a household's FoK provides insight into the 
household's zone of proximal development (Moll \& Greenberg, 1990), which can be applied to support learning at school.

Findings regarding FoK in Mexican communities (Velez-Ibanez, 1988) illustrate learning arising from interaction with others within a social and historical context, mediated by the use of cultural artifacts and social practices (Vygotsky, 1978). Use of students' and households' FoK in schools potentially creates classroom settings where this process is replicated. This means that students learn to use important cultural tools, including reading, writing, mathematics, and discourse modes, with the teacher actively "creating the social and cultural conditions for (this) socialization into 'authentic' literacy practices” (Moll, 1992, p. 21), and taking on a learning role together with the students (Gonzalez et al., 2005). Formal learning supports students to gain knowledge and skills that are relevant to their life goals (Upadhyay, 2005). This approach is contrary to pedagogies in which skills are developed discretely and decontextualised from life tasks and goals.

Therefore, the use of community socio-cultural resources to support classroom learning is fundamental to the FoK concept. These resources are potentially widely diverse (Velez-Ibanez, 1988), and could include bilingualism, expertise from paid and unpaid work, and cultural skills and knowledge. For instance, Moll (1992) describes the work of a teacher who, over the course of a semester, invited about 20 "parents and others in the community to contribute intellectually to the development of lessons; in our terms, she started developing a social network to access FoK for academic purposes” (p. 23). In this model the teacher facilitates social relationships, uses these to engage students in academic tasks, and provides meaningful, authentic learning experiences which are relevant to the students' lives. Therefore, language and literacy are used as tools for functional and purposeful uses (Moll \& Whitmore, 1993). This socio-cultural approach is a "participatory or apprenticeship model of instruction" (Moll, 1992, p. 21), which arguably promotes intrinsic motivation for learning. The establishment of such an environment is a pre-requisite for productive learning (Nelson, 2001). These practices strategically draw on students' FoK to add to them in school, thus also creating an 
emotionally safe environment where the children's identities are fully accepted and valued.

Vygotsky perceives "learning and development as dynamic processes, social, cultural and historical by nature, and in a dialectical relationship with each other" (Wink \& Putney, 2002, p. 62). Moll and Whitmore (1993) argue that understanding and application of the zone of proximal development needs to take this into account, recognising the importance of use of social interaction and semiotic tools, together with "a focus on meaning" (p. 39), compatible with Vygotsky's (1978) views of humans acting to transform their lives, with the help of cultural tools. A key element within this is the paramount importance of students' life goals and values, which provide the purpose of learning, thus influencing their perspectives relating to the relevance of specific learning experiences.

\section{Lave and Wenger}

Citations of Lave and Wenger's work, especially their theory of situated learning, were found in 10 of the 50 texts reviewed.

Lave and Wenger (1991) describe communities of practice (CoPs), such as those that operate in every subject discipline, and in diverse fields of human activity. The various components of a student's lifeworld form a personalised local set of CoPs (Erickson, 2007) in which s/he is involved. Each has its own activity focus and discourse (ways of knowing and being, as well as inter-personal and intrapersonal communication associated with discourse: ways of talking, thinking, interacting, reading and writing) (Gee, 1996, 1999). Therefore, members gain specific FoK, which are essentially situated within the CoP activity.

Learning in CoPs happens through peripheral participation: individuals learn the highly contextualised activity of a CoP through interaction with other more expert individuals. Possible experts include parents and community members (Bouillion \& Gomez, 2001), other students (Lee, 2001), or the teacher (Barton \& Tan, 2009). Thus gradually students develop discourse to allow increased participation (Smythe \& Toohey, 2009); with greater mastery comes a stronger sense of identity within that CoP. This occurs across all types of CoPs; 
when teachers enter household or community settings, to learn about students' FoK, they too start with peripheral involvement, which will gradually change with time and familiarisation (Gonzalez \& Moll, 2002).

In schools, academic CoPs support students to develop expertise, and contribute to identity formation as students learn not only the subject, but also its discourse. Obstacles for minority students arise from the "exclusive nature of school science culture ... (which is) sometimes in conflict with the ways of being of students from nondominant cultures” (Barton \& Tan, 2009, p. 51). For learning to happen in schools, students as members need access to the tools, practices and artifacts of the $\mathrm{CoP}$, including its language (Barton \& Tan, 2009). A student's motivation can be eroded by access constraints, leading to marginalisation and non-participation (Fitts, 2009). Thus the teacher's role, as the designer of classroom interaction and learning experiences, is pivotal. To be relevant to students' lives, the learning context must relate to their experiences, that is, their personal CoPs and the associated FoK. As well, interaction within the classroom CoP must generate new knowledge (Lave \& Wenger, cited in Upadhyay, 2005).

Fitts (2009) states that, in bilingual and bicultural classrooms, peripheral involvement can be very supportive to minority ethnicity students, but when such students are given opportunities to take on central, expert roles, benefits from privileging their perspectives and knowledge arise for both the minority ethnicity and dominant culture students. This necessitates teacher knowledge of the local CoPs that minority ethnicity students inhabit - which are the sites, contexts, and activities from which students gain FoK - and use of these to guide professional practice. Arguably this principle is important in all school settings where diverse groups have different levels of access to relevant tools, artifacts and discourse, necessitating different levels of support for the successful apprenticeship of different students into high status academic CoPs. 


\section{Critical theory}

As early as 1990, FoK scholars identified their concerns regarding class distinctions in schooling practice and quality, and the impact of the "hidden curriculum" for working class children (Giroux, cited in Moll et al., 1990), effectively making classrooms "zones of underdevelopment" (Greenberg, cited in Moll et al., 1990, p. 5). However, from 1995, literature within the field reflected more strongly alignment of the FoK concept with critical theory. Five critical theorists are cited in the studies reviewed; of these, the most frequently cited were Giroux, Freire, and Bourdieu. The ideas of these three theorists pertaining to FoK are described below.

\section{Giroux}

Giroux $(1983,1985)$ is the critical theorist first cited by writers in this field; his work is cited in eight of the 50 texts. His influence can be seen in FoK project aims, and includes achievement of "pivotal and transformative shifts in teacher attitudes and behaviors and in relations between households and schools and between parents and teachers" (Gonzalez, et al., 1995, p. 444), positioning teachers as agents of change (Giroux, 1985). Teachers' professional practice can potentially transform possibilities for "disenfranchised" students (Hattam et al., 2009, p. 304). This eventuality is dependent on a number of factors. First, it depends on teachers' acceptance that education is a political act, sited in schools that are "contradictory social sites" for marginalised students (Giroux, cited in Upadhyay, 2009, p. 217). Secondly, teachers need to appreciate the politicised nature of diversity issues (Gonzalez \& Moll, 2002). Thirdly, development of teacher self-awareness of cultural identity and impacts on attitudes and behaviours are necessary. Finally, transformative education requires teacher commitment to actions to minimise cultural incongruency experienced by minority ethnicity students.

\section{Freire}

Critical pedagogy (Freire, cited in Antrop-Gonzalez \& De Jesus, 2006), which draws out and values student voice and creation of knowledge from their lived reality (Giroux, cited in Gonzalez \& Moll, 2002), addresses several factors needed for transformative education. 
Four texts identified critical pedagogy as the conceptual basis. The application of FoK in classrooms counteracts social, political and cultural forces which dominate knowledge construction (Basu \& Barton, 2007) by generating themes for learning from students' current life situation. In this model, the teacher is also a learner, facilitating praxis: reflection and action for the purpose of transformation (Freire, 1970). Furthermore, Freire's (1981) conceptualisation of dialogue as an "emancipatory educational process" is a key feature of application of the FoK concept, which values not only student voice, but also the voices of their families and community. Dialogue thus validates experience and knowledge, breaks down borders between knowledge and power, and inspires personal transformation (Gonzalez, 1995).

\section{Bourdieu}

Since 2001, researchers have increasingly situated the work within Bourdieu's theory of cultural capital as a mechanism for maintaining the class system. Thirteen texts included citations of Bourdieu (1977, 1986, Bourdieu \& Passeron, 1977). A FoK approach can potentially disrupt the "symbolic violence" (Bourdieu \& Passeron, 1977, cited in Barton \& Tan, 2009, p. 70) of dominant academic discourse (Gonzalez et al., 2001), pedagogical practices (Barton \& Tan, 2009; Gonzalez et al., 2001; Gonzalez et al., 2005; Gonzalez \& Moll, 2002; Hattam et al., 2009; Moje et al., 2004; Smythe \& Toohey, 2009; Upadhyay, 2005; Zipin, 2009), and assessment practices (Klenowski, 2009; Lee, 1998).

When teacher practice draws on knowledge and habitus arising from their own social field, the congruence between their own background and experience and that of culturally-similar students covertly perpetuates class distinctions. The individual habitus of students from minority groups, at the intersection of contradictory and/or conflicting social fields, leaves these 'other' students in danger of experiencing school as unfamiliar, uncomfortable, and alienating (Dimitriadis \& Kamberelis, 2006).

Thus critical theory is concerned with the impact of pedagogical practice on the powerlessness of students from groups lacking the 
cultural capital of the dominant culture. Drawing on students' FoK can make cultural capital "explicit and practicable" for all (Delpit, cited in Zipin, 2009, p. 318) by validating the academic worth of household practice and praxis (Gonzalez et al., 2001), scaffolding new learning from the everyday to the academic (Moll \& Greenberg, 1990; Zipin, 2009), supporting students to navigate new areas of knowledge from different disciplines, and by enabling construction of new knowledge through discussion of competing discourses and knowledge (Moje et al., 2004). Zipin (2009) further argues that FoK, in providing a model of students' and households' lifeworld knowledge, for lifeworld goals, reclaims the value of this knowledge, inherently challenging the superior value of cultural capital associated with market rather than lifeworld value.

\section{Other theories}

Other theoretical frameworks that less frequently provide the conceptual foundation for FoK work are hybridity theory, systems theory and the difference theory of caring, described below.

\section{Hybridity theory}

Four of the studies examined located the concept within the field of hybridity theory (Barton \& Tan, 2009; Fitts, 2009; Moje, et al., 2004; Varelas \& Pappas, 2006). Hybridity theory, developed by Bhabha (1994), acknowledges numerous complex resources drawn on by people in our globalised environment. The theory describes the possibility of being “'in-between' several different Funds of Knowledge and Discourse (which) can be both productive and constraining in terms of one's literate, social, and cultural practices and, ultimately, one’s identity development” (Moje et al., 2004, p. 42).

Hybrid, "in-between” (Bhabha, 1994, p. 1) space is also called third space by some academics. Third space provides a context for interaction, in which knowledge and discourses from first space (home, peer groups and community) may be considered alongside those from second space (formalised institutions, including schools, church, and workplaces), to begin to resolve competing knowledges and discourses. In third spaces, "students' linguistic and cultural 
forms, styles, artifacts, goals, of ways of relating interpenetrate and transform the official linguistic and cultural forms of the school, teacher, or classroom” (Gutierrez, Banquedano-Lopez, \& Tejada, cited in Fitts, 2009).

There are three views on the role of hybrid space, all of which Moje et. al., (2004), Barton and Tan (2009), and Fitts (2009) perceive as relevant to FoK research. Firstly, creation of hybrid space can scaffold academic learning by linking it to FoK. Secondly, it can operate as "navigational space” (Barton \& Tan, 2009, p. 52) to support growing expertise to negotiate different discourse communities. However, FoK scholars citing hybridity theory argue that FoK best relates to a view of third space as a space where competing knowledges and discourses can be addressed, allowing transformational possibilities for the creation of new understandings and new knowledge, and agree that this view represents the ultimate goal of education (Barton \& Tan, 2009; Fitts, 2009; Moje et al., 2004). This last view of hybrid space is particularly relevant to ethnic minority students, whose knowledge from first space is more likely to be incongruent with the dominant academic discourse (Moje et. al., 2004). Fitts (2009) notes that this last view of third space is also the most challenging.

In their discussion of third space, FoK scholars make links to socio-cultural learning theory. For instance, Varelas \& Pappas (2006) state the value of "dialogically oriented instruction" (p. 220) which allows students to share their knowledge and experiences from first space, and reflect on how these FoK connect to scientific concepts presented in academic language, thus supporting co-construction of knowledge. Moje et. al. (2004) note that some hybridity scholars emphasise the importance of third space as "physical, as well as socialized" (p. 42), highlighting links between this theory and sociocultural theories of learning. Fitts (2009) explains that in third spaces, "new hybrid CoPs" (Gutierrez, Banquedano-Lopez, \& Tejada, cited by Fitts, 2009, p. 90) are created, and in these, as in other CoPs, less knowledgeable members learn from peripheral participation alongside experts within the group. Fitts (2009) points out that a benefit arising from the creation of third space is that, because bilingualism and 
multiculturalism are recognised as relevant and educative, marginalised students may take on more central roles in their CoPs. She explains that this in turn creates the possibility of a deeper level of active involvement for marginalised students, and offers the opportunity for students from the dominant culture to gain wider perspectives and knowledge. Barton and Tan (2009) describe their interest in hybridity theory thus:

We have observed how youth take up knowledges, resources, and identities that often go unsanctioned in school. In so doing, they author new identities, drawing from nontraditional funds and discourses to renegotiate their boundaries of their participation in class in ways that allow them to build their social identities while establishing epistemic authority. (pp. 52-53).

This statement highlights the potential of hybridity theory to present a constructivist model of schooling which engages with students from where they are at, is comfortable with the notion of multiple perspectives, and offers the possibility of students' enhancing and expanding their sense of personal identity.

\section{Systems Theory}

Systems theory was cited by one study. Patterson and Baldwin (2001) point out similarities between school community systems, with components such as classrooms and families, and systems in nature such as ecosystems, citing work by scientists, including Capra (1996), Eoyang (1997), and Gell-Mann (1994). Capra (1996), himself a physicist, describes the transdisciplinary nature of systems theory and relates it to an ecological view, due to its perspective of the world as a large complex system made up of an integrated, interdependent set of parts.

Importantly, systems have a self-organising quality due to the interdependence of components: incoming information and energy lead to participant responses and behaviours, which in turn form patterns, and ultimately influence system-wide phenomena (Eoyang, 1997). Thus systems theory describes the in-built adaptive quality of systems in response to inevitable change. The organic self-organising nature of system adaptivity is highlighted by Patterson and Baldwin's 
(2001) observation that they were unconscious of their own adaptive behaviours after finding out about students' FoK until they reflected back on the process.

Systems theory states that when barriers to information are removed, new information becomes available, or feedback is received, information flow through all components is affected and the system adjusts to accommodate the new information or circumstances. As Patterson and Baldwin (2001) state, "our new understandings made it necessary for us to change our teaching” (p. 130). They describe the "overlapping and interactive" systems - including home and school - which all form part of a child's education, and conclude that work "at the boundaries between and among complex systems" (p. 132) incorporating "both inquiry and conversation” (p. 132) is critical. Accordingly, they describe the professional role of teachers as "reaching out” (p. 133) to families, to learn and gather evidence about their students to inform professional decision-making.

In summary, a systems approach theorises that drawing on FoK will facilitate adaption within a complex school system, through minimising isolation or misinformation relating to some system components. By engaging in inquiry about students and their families, teachers open up information flow and enhance the quality of information which can inform their practice. Patterson and Baldwin articulate their vision thus: "From a systems perspective, we want to help all these separate and sometimes isolated systems come together into larger, more complex systems that respond better to changing needs and to new circumstances” (p. 138).

\section{Difference theory of caring}

As well as locating their work within critical theory, Antrop-Gonzalez and De Jesus (2006) examine FoK within the context of contested notions of caring in schools. They advance a critical care framework, primarily developed from McKamey's difference theory of caring (cited in Antrop-Gonzalez \& De Jesus, 2006). The difference theory of caring states that inclusive schools incorporate definitions of caring from different ethnic and class groups within their school community. Notions of caring that incorporate feelings of pity and low 
expectations are rejected by difference scholars. These theorists also draw attention to the conflict that can arise between teachers and community members, each believing that the other doesn't care, regarding each other's expressions of care as inauthentic, due to differences in caring philosophy and practice (Valenzuela, 1999). For example, Thompson (1998) describes caring in Black communities as a "public undertaking” (as cited in Antrop-Gonzalez \& De Jesus, 2006, p. 412), whereas Valenzuela reports that teachers show care "with an abstract, or aesthetic commitment to ideas and practices that purportedly lead to achievement" (as cited in Antrop-Gonzalez \& De Jesus, 2006, p. 412).

Antrop-Gonzalez and De Jesus' (2006) theory of critical care aims to address both the need for culturally relevant caring, and notions of social and cultural capital. They define critical care as featuring both "supportive instrumental relationships and high academic expectations” (p. 413). They see application of the FoK concept as essential within a critical care framework, because it allows the establishment of "culturally additive learning communities" (p. 413), and the development of “critical and caring curricula” (p. 417), which collectively have transformational potential for students and their communities. In conclusion, the essential starting point for development of a critical care framework must include teacher investigation of concepts of caring held within the community, which are essentially an element of students' FoK.

Table 2 below summarises information from the findings section of this paper, by showing key ideas from each conceptual framework presented by FoK scholars, and statements about implications for learning and other gains for students that arise from different theories. 


\section{Table 2: Key ideas and implications for practice brought into focus by different theoretical frameworks of funds of knowledge research}

\begin{tabular}{|c|c|c|}
\hline $\begin{array}{l}\text { Theoretical } \\
\text { framework }\end{array}$ & Key ideas & $\begin{array}{l}\text { Implications regarding what } \\
\text { students potentially learn or gain } \\
\text { when the funds of knowledge } \\
\text { concept is applied }\end{array}$ \\
\hline $\begin{array}{l}\text { Socio-cultural } \\
\text { learning theory }\end{array}$ & $\begin{array}{l}\text { Learning results from authentic, } \\
\text { meaningful interactions with others; } \\
\text { - Community sociocultural resources can } \\
\text { support academic learning; } \\
\text { Gains from teacher knowledge of } \\
\text { household zone of proximal } \\
\text { development; } \\
\text { - Students are members of diverse CoPs } \\
\text { associated with their fields of activity, } \\
\text { each with specific discourse; } \\
\text { - Learning occurs through peripheral } \\
\text { participation and interaction with } \\
\text { individuals who are more expert; } \\
\text { - Classroom learning needs to relate to } \\
\text { students' CoPs; } \\
\text { Academic learning must develop } \\
\text { knowledge of the subject discourse as } \\
\text { well as content; } \\
\text { Mastery of subject discourses } \\
\text { contributes to identity formation. }\end{array}$ & $\begin{array}{l}\text { - Validation of academic value of } \\
\text { knowledge held in all } \\
\text { communities; } \\
\text { - Development in skills for use } \\
\text { of cultural tools such as } \\
\text { reading, writing, mathematics } \\
\text { and models of discourse to } \\
\text { support life goals; } \\
\text { - Classroom learning is authentic } \\
\text { and contextualised; } \\
\text { - Apprenticeship of students into } \\
\text { academic CoPs is tailored } \\
\text { according to the support } \\
\text { needed; } \\
\text { - Knowledge of academic CoPs; } \\
\text { Benefits for all students when } \\
\text { ethnic minority students and } \\
\text { community members take } \\
\text { expert roles and share their } \\
\text { perspectives and knowledge. }\end{array}$ \\
\hline Critical theory & $\begin{array}{l}\text { The schooling experience can be } \\
\text { culturally incongruent for students from } \\
\text { outside the dominant culture, } \\
\text { disadvantaging certain groups and } \\
\text { reinforcing existing class structure; } \\
\text { - Effective educators for social justice are } \\
\text { aware of themselves as cultural beings, } \\
\text { see teaching as a political act, and are } \\
\text { committed to minimisation of cultural } \\
\text { incongruency for disadvantaged } \\
\text { students; } \\
\text { Teacher practice is potentially } \\
\text { transformative for disadvantaged } \\
\text { students; } \\
\text { - Teacher as learner, facilitating praxis; } \\
\text { The value of student voice, and voices } \\
\text { of family and community members; } \\
\text { The emancipatory power of dialogue. }\end{array}$ & $\begin{array}{l}\text { - Validation of experience and } \\
\text { knowledge; } \\
\text { - Creation of knowledge from } \\
\text { lived reality; } \\
\text { - More equitable access to high } \\
\text { status cultural capital. }\end{array}$ \\
\hline
\end{tabular}




\begin{tabular}{|c|c|c|}
\hline $\begin{array}{l}\text { Theoretical } \\
\text { framework }\end{array}$ & Key ideas & $\begin{array}{l}\text { Implications regarding what } \\
\text { students potentially learn or gain } \\
\text { when the funds of knowledge } \\
\text { concept is applied }\end{array}$ \\
\hline Hybridity theory & $\begin{array}{l}\text { Hybrid space provides a context for } \\
\text { considering discourse from personal } \\
\text { CoPs, alongside academic and } \\
\text { institutional knowledge and discourse. }\end{array}$ & $\begin{array}{l}\text { - Academic learning can be } \\
\text { scaffolded from individual } \\
\text { funds of knowledge; } \\
\text { - Hybrid space allows navigation } \\
\text { of discourse from academic } \\
\text { CoPs; } \\
\text { - Learning gains arise from } \\
\text { addressing competing } \\
\text { knowledges and discourses. }\end{array}$ \\
\hline Systems theory & $\begin{array}{l}\text { - Information flow between system } \\
\text { components affects system functioning } \\
\text { and outputs; } \\
\text { - Isolation of system components limits } \\
\text { system effectiveness. }\end{array}$ & $\begin{array}{l}\text { - Improved effectiveness of } \\
\text { classroom practice from greater } \\
\text { information flow between } \\
\text { family and school. }\end{array}$ \\
\hline $\begin{array}{l}\text { Difference } \\
\text { theory of caring }\end{array}$ & $\begin{array}{l}\text { - Inclusive schools draw on culturally } \\
\text { diverse definitions of caring; } \\
\text { - Curricula can be “critical and caring.” }\end{array}$ & $\begin{array}{l}\text { Development of culturally } \\
\text { relevant definitions of caring; } \\
\text { - Culturally relevant conceptions } \\
\text { of caring are transformative for } \\
\text { students and the community. }\end{array}$ \\
\hline
\end{tabular}

\section{Discussion and recommendations}

\section{Theoretical congruence and implications for research}

FoK work is clearly located within the field of education for social justice. This is evident from statements describing the background and rationale for studies, as well as the political theoretical frameworks in which work is located. All academics working with the FoK concept ultimately aim to create more effective schooling for marginalised students, and feature disproportionately in other negative indicators, such as school drop-out - or "push-out" - rates (Antrop-Gonzalez \& De Jesus, 2006, p. 420).

Although the present analysis of studies revealed some differences in the conceptual basis identified for FoK scholars, fundamental alignment within the field of education for social justice was maintained. For instance, the difference theory of caring, which grounds work by Antrop-Gonzalez and De Jesus (2006), is well 
aligned with understandings from critical theory, such as Bourdieu's (1986) theory of cultural capital as a device for maintaining class structure, highlighting the potential for schools, possibly dysconsciously (King, 2004), to impose particular cultural norms in their definitions of 'the way we do things around here.' Difference theorists critique White feminist caring theories as flawed by "color and power blindness” (Antrop-Gonzalez \& De Jesus, 2006, p. 411). The critical care framework explicitly aims to describe school practices which are transformational (Freire, 1970) for students and their communities.

Similarly, all writers who ground their work in hybridity theory cite either Vygotsky or Lave and Wenger, and three of the four also cite Bourdieu; these scholars uniformly conceptualise FoK as a way to utilise socio-cultural learning processes to support the development of high-status cultural capital. As well, socio-cultural theory, critical theory and hybridity theory all recognise the value of household praxis, scaffolding from the familiar, and apprenticing students into academic discourse communities. Bhabha's (1994) postcolonial model of third space, characterised by sharing and reflection on multiple perspectives to create new understandings and knowledge, suggests alignment also with the values of critical theory. As Moje et al. (2004) explain: "Bhabha's view of third space suggests that academic knowledges and discourses need not be accorded an absolute and exclusive privilege, precisely because there is potential for the rearticulation of both academic and everyday knowledges, as well as of the discourses constituted by the communities that produce such knowledges” (p. 43).

Systems theory's focus on inter-relationships between system elements has congruence with socio-cultural theory, and also aligns with hybridity theory's notions of spaces. However, both hybridity theory and socio-cultural theories of learning are specifically concerned with describing and achieving the conditions needed to generate effective learning. Systems theory, however, has a wider perspective, postulating that the flow and quality of information in systems will result in self-organisation at component level, therefore determining system effectiveness. Systems theory, with its emphasis 
on the holistic, can illuminate complex systemic issues which arise due to the interconnectedness and interdependence of elements and systems, in what Capra (1996) terms "the web of life," and can be applied to strategically address a range of complex problems.

Differences in the stated conceptual basis for FoK work also arguably relate to application of the concept in a variety of contexts, and for a variety of purposes. I believe that the diversity within conceptual bases offered for this work strengthens the links between the FoK concept and educational philosophy, and that the current range of conceptual frameworks does not constrain future discussion.

A significant proportion of texts reviewed did not identify the conceptual basis for their work, raising questions about what theoretical frameworks were drawn on for these works, and how important it is to state these. Potentially full discussion of theoretical frameworks may facilitate thinking about the possible rationale for work in the field, potentially providing powerful arguments for the consideration and application of the FoK concept by teachers and teacher educators. Arguably the range of theoretical frameworks identified may further develop richness of understanding of current levels of knowledge about the relevance of the FoK concept for schools. As a student in the field and a teacher educator, I encourage researchers in their future work to clearly outline the underpinning conceptual framework. This practice will enable each study to be clearly located within the body of work, and support the coherent and clear development of new knowledge in the field.

\section{Implications for multicultural education}

As signalled by the alignment of FoK work with socio-cultural learning theorists, critical theorists, hybridity theorists, and difference theorists of caring, drawing on students' FoK creates benefits which potentially relate to a number of dimensions of multicultural education. Banks (2004) identified these as content integration, the knowledge construction process, prejudice reduction, equity pedagogy and an empowering school culture and social structure. When teachers seek to understand more clearly minority ethnicity students by looking to identify individuals' FoK, then potentially this could generate new 
models of interaction between the students and their dominant-culture teachers. Therefore, the development of an empowering school culture which potentially can arise from a FoK approach, addresses concerns about the balance of power in classrooms (Bishop 2005; Bishop \& Glynn, 1999). Reframing teachers as learners and students as teachers in this way, in accordance with the Maori concept of ako (reciprocal teaching and learning), is a key element of culturally safe classrooms for Maori (Bishop et al., 2003; Cavanagh, 2005; Tangaere, 1997). Explicit engagement of students' and community members' FoK may promote content integration and provide diverse perspectives to complement dominant viewpoints. This may subvert implicit cultural assumptions often inherent in the knowledge construction process, and address New Zealand scholars' concerns about Maori knowledge devaluation and the need to break free from an assimilative model to reciprocal sharing of cultural knowledge. As Banks (1996) argued, such an approach also potentially may be transformative, raising awareness of the irrefutable subjectivity of knowledge, and the richness of the lifeworld experience of students commonly subjected to deficit theorising. Sharing of this knowledge between students, depending on the dynamics of the school and classroom environment (Allport, 1954), may result in prejudice reduction. Arguably an equity pedagogy is more likely to be achieved with increased teacher knowledge and utilisation of household pedagogies.

\section{Conclusion}

A specific political perspective and set of common values underpin socio-cultural learning theory, critical theory, hybridity theory, and difference theories of caring. However, arguably, in order to apply systems theory for the interests of ethnic minority students, educators need to hold attitudes and beliefs that recognise and value these students, their families and communities, as well as their FoK. Although this statement sounds simple, the achievement is apparently not. However, this understanding and its application is a feature of effective teachers (Garcia, 1994; Olsen \& Mullen, 1990). As Sonia Nieto (2010) eloquently stated, 
The first and foremost lesson I learned as a novice teacher was this: build on what your students know. In spite of its simplicity and exquisite common sense, this idea is radical because it is based on the judgement that intelligence is not the sole province of students from specific groups, but of all students regardless of their identity and status. Unfortunately, however, bicultural students very often are thought not to have any strengths upon which to build. (p. 135)

Deficit theorising, despite considerable flaws, has enjoyed a longstanding and privileged position within education scholarship (Bishop, 2005; Lee, 2009; Valencia, 2010). Are traditional deficit discourses so firmly embedded that a concept such as FoK which asserts the fundamental skills and knowledge of all children struggles to achieve credence in the attitudes, beliefs and practices of educationalists? As Nieto (2010) states, curriculum and pedagogy can be seen simply as the application of beliefs and values, reflecting the teacher's or the imposed educational system's ideology. With this in mind, nothing short of transforming values and beliefs will achieve changes in classroom practice to support social justice aims. Therefore, I would argue that achieving transformative changes in thinking and classroom practices will benefit from the support of strong, clear and persuasive discussion of researchers' underlying theoretical frameworks.

\section{References}

Allport, G. W. (1954). The nature of prejudice. Reading, MA: Addison-Wesley. Andrews J., \& Yee, W. C. (2006). Children's funds of knowledge and their real life activities: Two minority ethnic children learning in out-of-school contexts in the UK. Educational Review, 58(4), 435-449.

Antrop-Gonzalez, R., \& De Jesus, A. (2006). Toward a theory of critical care in urban small school reform: Examining structures and pedagogies of caring in two Latino community-based schools. International Journal of Qualitative Studies in Education, 19(4), 409-433.

Archer, L., \& Francis, B. (2007). Understanding minority ethnic achievement: Race, gender, class and 'success.' Abingdon, Oxon: Routledge.

Artiles, A. J., Klingner, J. K., \& Tate, W. F. (2006). Representation of minority students in special education: Complicating traditional explanations. Educational Researcher, 35(6), 3-5. 
Banks, J. A. (1996). Multicultural education, transformative knowledge, and action: Historical and contemporary perspectives. New York: Teachers College Press.

Banks, J. A. (2004). Multicultural education: Historical development, dimensions, and practice. In J. A. Banks \& C. A. M. Banks (Eds.), Handbook of research on multicultural education (2nd ed., pp. 3-29). San Francisco, CA: Jossey-Bass.

Banks, J. A. \& Park, C. (2010). Race, ethnicity, and education: The search for explanations. In P. Hill Collins \& J. Solomos (Eds.), The Sage handbook of race and ethnic studies (pp. 383-414). London: Sage.

Barton, A. C., \& Tan, E. (2009). Funds of knowledge and discourses and hybrid space. Journal of Research in Science Teaching, 46(1), 50-73.

Basu, S. J., \& Barton, A. C. (2007). Developing a sustained interest in science among urban minority youth. Journal of Research in Science Teaching, 44(3), 466-489.

Bhabha, H. K. (1994). The location of culture. New York: Routledge.

Biddulph, F., Biddulph, J., \& Biddulph, C. (2003). The complexity of community and family influences on children's achievement in New Zealand: Best evidence synthesis. Wellington, New Zealand: Ministry of Education.

Bishop, R. (2005). Pathologizing the lived experiences of the indigenous Māori people of Aotearoa New Zealand. In C. M. Shields, R. Bishop, \& A. E. Mazawi, Pathologizing practices: The impact of deficit thinking on education (pp. 55-84). New York: Peter Lang.

Bishop, R., \& Glynn, T. (1999). Culture counts: Changing power relations in education. Palmerston North: Dunmore Press.

Bishop, R., Berryman, M., Tiakiwai, S., \& Richardson, C. (2003). Te Kotahitanga Phase 1: The experiences of year 9 and 10 Màori students in mainstream classrooms: Report to the Ministry of Education. Wellington: Learning Media.

Bouillion, L., \& Gomez, L. (2001). Connecting school and community with science learning: Real world problems and school-community partnerships as contextual scaffolds. Journal of Research in Science Teaching, 38(8), 878-898.

Bourdieu, P. (1977). Outline of a theory of practice. Cambridge: Cambridge University Press.

Bourdieu, P. (1986). The forms of capital. In J. G. Richardson (Ed.), Handbook of theory and research for the sociology of education (pp. 241-258). New York: Greenwood Press.

Bourdieu, P., \& Passeron, J. C. (1977). Reproduction in culture, education and society. London: Sage.

Capra, F. (1996). The web of life: A new scientific understanding of living systems. New York: Anchor Books, Doubleday. 
Cavanagh, T. (2005). Restoration practices and a culture of care in schools: A story of alternative positive peace efforts. Preliminary report to Raglan Area School, Raglan, New Zealand.

Civil, M., \& Bernier, E. (2006). Exploring images of parental participation in mathematics education: Challenges and possibilities. Mathematical Thinking and Learning, 8(3), 309-330.

Department for Education and Skills (DfES) (2004). Every child matters: Change for children. London: DfES.

Dimitriadis, G., \& Kamberelis, G. (2006). Theory for education. New York: Routledge.

Eoyang, G. H. (1997). Coping with chaos: Seven simple tools. Cheyenne, WY: Lagumo.

Erickson, F. (2007). Culture in society and in educational practices. In J. A. Banks \& C. A. M. Banks (Eds.), Multicultural education: Issues and perspectives ( $6^{\text {th }}$ ed., pp. 33-61). Hoboken, NJ: John Wiley.

Fitts, S. (2009). Exploring third space in a dual-language setting: Opportunities and challenges. Journal of Latinos and Education, 8(2), 87-104.

Freire, P. (1970). Pedagogy of the oppressed. New York: Continuum.

Freire, P. (1981). Education for critical consciousness. New York: Continuum.

Garcia, E. E. (1994). Understanding and meeting the challenge of student cultural diversity. Boston, MA: Houghton Mifflin.

Gee, J. P. (1996). Social linguistics and literacies: Ideology in discourses. London: Falmer Press.

Gee, J. P. (1999). An introduction to discourse analysis: Theory and method. London: Routledge.

Gell-Mann, M. (1994). The quark and the jaguar: Adventures in the simple and the complex. New York: W. H. Freeman.

Giroux, H. A. (1983). Theory and resistance in education: A pedagogy for the opposition. South Hadley, MA: Bergin \& Garvey.

Giroux, H. A. (1985). Teachers as transformative intellectuals. Social Education, 2, 376-379.

Gonzalez, N. (1995). Processual approaches to multicultural education. Journal of Applied Behavioural Science, 3, 234-244.

Gonzalez, N. (2005). The hybridity of funds of knowledge. In N. Gonzalez, L. C. Moll \& C. Amanti (Eds.), Funds of knowledge: Theorizing practices in households, communities and classrooms (pp. 29-46). New Jersey: Lawrence Erlbaum.

Gonzalez, N., \& Moll, L. (2002). Cruzando el Puente: Building bridges to funds of knowledge. Educational Policy, 16, 623-641.

Gonzalez, N., Andrade, R., Civil, M., \& Moll, L. (2001). Bridging funds of distributed knowledge: Creating zones of practices in mathematics. Journal of Education for Students Placed At Risk, 6(1\&2), 115-132. 
Gonzalez, N., Moll, L., \& Amanti, C. (2005). Introduction: Theorizing practices. In N. Gonzalez, L. C. Moll \& C. Amanti. (Eds.), Funds of Knowledge: Theorizing practices in households, communities and classrooms (pp. 128). New Jersey: Lawrence Erlbaum.

Gonzalez, N., Moll, L., Floyd Tenery, M. F., Rivera, A., Rendon, P., Gonzales, R., \& Amanti, C. (1995). Funds of knowledge for teaching in Latino households. Urban Education, 29(4), 443-470.

Gregory, A., Skiba, R. J., Noguera, P. A. (2010). The achievement gap and the discipline gap: Two sides of the same coin? Educational Researcher, 39(1), 59-68.

Hammond, L. (2001). Notes from California: An anthropological approach to urban science education for minority language families. Journal of Research in Science Teaching, 38(9), 983-999.

Hattam, R., \& Prosser, B. (2008). Unsettling deficit views of students and their communities. The Australian Educational Researcher, 35(2), 89-106.

Hattam, R., Brennan, M., Zipin, L., \& Comber, B. (2009). Researching for social justice: Contextual, conceptual and methodological challenges. Discourse: Studies in the Cultural Politics of Education, 30(3), 303-316.

Hogg, L. (2011). Funds of knowledge: An investigation of coherence within the literature. Teaching and Teacher Education, 27(3), 666-677.

Hughes, M., \& Greenhough, P. (2006). Boxes, bags and videotape: Enhancing home-school communication through knowledge exchange activities. Educational Review, 58(4), 471-487.

Hughes, M., \& Pollard, A. (2006). Home-school knowledge exchange in context. Educational Review, 58(4), 385-395.

Hugo, G. (2000). The demographics of the school age population in Australia. Retrieved April 30, 2010, from http://www.ais.sa.edu.au/resources/ Demographics\%20of\%20the\%20School\%20Age\%20Pop\%20Pgs\%20124.pdf

Irizarry, J. G. (2009). Representin': Drawing from hip-hop and urban youth culture to inform teacher education. Education and Urban Society, 41, 489-515.

KewelRamani, A., Gilbertson, L., Fox, M., \& Provasnik, S. (2007). Status and trends in the education of racial and ethnic minorities (NCES 2007-039). Washington, DC: National Centre for Educational Statistics, Institute of Education Sciences, U.S. Department of Education. Retrieved May 27, 2010, from http://nces.ed.gov/pubs2007/2007039.pdf

King, J. E. (2004). Dysconscious racism: Ideology, identity and the miseducation of teachers. In G. Ladson-Billings \& D. Gillborn (Eds.), The Routledge-Falmer reader in multicultural education (pp. 71-83). London: Routledge-Falmer. 
Klenowski, V. (2009). Australian indigenous students: Addressing equity issues in assessment. Teaching Education, 20(1), 77-93.

Lave, J., \& Wenger, E. (1991). Situated learning: Legitimate peripheral participation. New York: Cambridge University Press.

Lee, C. D. (1998). Culturally responsive pedagogy and performance-based assessment. The Journal of Negro Education, 67(3), 268-279.

Lee, C. D. (2001). Is October Brown Chinese? A cultural modeling activity system for underachieving students. American Educational Research Journal, 38(1), 97-141.

Lee, C. D. (2009). Historical evolution of risk and equity: Interdisciplinary issues and critiques. Review of Research in Education, 33, 63-100.

McFarlane, A. H., Glynn, T., Grace, W., Penetito, W., \& Bateman, S. (2008). Indigenous epistemology in a national curriculum framework? Ethnicities, 8(1), 102-127.

Menchaca, M. (1997). Early racist discourses: Roots of deficit thinking. In R. R. Valencia (Ed.), The evolution of deficit thinking: Educational thought and practice (pp. 13-40). London: Falmer Press.

Ministry of Education (2005). Ministry of Education suspension reduction initiative August 05. Retrieved March 25, 2010, from www.tki.org.nz/r/governance/.../suspensions_reduction_summary.doc.

Ministry of Education. (2007). A report on New Zealand student engagement 2006. Downloaded from www.educationcounts.govt.nz > ... > Student Engagement on 25 March 2010.

Ministry of Education. (2009). Ka Hikitia - Managing for success: The Maori education strategy, 2008-2012. Updated 2009. Wellington: Learning Media.

Moje, E. B., Ciechanowski, K. M., Kramer, K. Ellis, L., Carrillo, R., \& Collazo, T. (2004). Working toward third space in content area literacy: An examination of everyday funds of knowledge and discourse. Reading Research Quarterly, 39(1), 38-70.

Moll, L. C. (1992). Bilingual classroom studies and community analysis: Some recent trends. Educational Researcher, 21(2), 20-24.

Moll, L. C., \& Greenberg, J. B. (1990). Creating zones of possibilities: Combining social contexts for instruction. In L. C. Moll (Ed.), Vygotsky and education: Instructional implications and applications of sociohistorical psychology (pp. 319-348). Cambridge: Cambridge University Press.

Moll, L. C., \& Whitmore, K. F. (1993). Vygotsky in classroom practice: Moving from individual transmission to social interaction. In E. A. Forman, N. Mininck \& C. A. Stone (Eds.), Contexts for learning: Sociocultural dynamics in children's development (pp. 19-42). New York: Oxford University Press. 
Moll, L. C., Velez-Ibanez, C., Greenberg, J., Rivera, C., Andrade, R., Dworin, J., Fry, D., Saavedra, E., Tapia, J., \& Whitmore, K. (1990). Community knowledge and classroom practice: Combining resources for literacy instruction: Technical report. (OBEMLA Contract No. 300-87-0131). Tucson, AZ: University of Arizona College of Education and Bureau of Applied Research in Anthropology.

Moll, L., Amanti, C., Neff, D., \& Gonzalez, N. (1992). Funds of knowledge for teaching: Using a qualitative approach to connect homes and classrooms. Theory into Practice, 31(2), 132-141.

Nelson, G. (2001). Ways with community knowledge. PEN, 128, 3-9.

Nieto, S. (2010). The light in their eyes: Creating multicultural learning communities $\left(10^{\text {th }}\right.$ ed.) New York: Teachers College Press.

NZQA (2010). Qualifications by year level and ethnicity. Retrieved 28 May 2010 from http://www.nzqa.govt.nz/qualifications/ssq/statistics/providerselected-crystalreport.do.

Olmedo, I. M. (2004). Raising transnational issues in a multicultural curriculum project. Urban Education, 39, 241-265.

Olsen, L. \& Mullen, N. A. (1990). Embracing diversity: Teachers' voices from California's classrooms. San Francisco, CA: California Tomorrow.

Patterson, L., \& Baldwin, S. (2001). A different spin on parent involvement: Exploring funds of knowledge within a systems perspective. In W. Goodman (Ed.), Living and teaching in an unjust world: New perspectives on multicultural education (pp. 127-139). Portsmouth, NH: Heinemann.

Penetito, W. (2001). If only we knew... contextualizing Māori knowledge. In B. Webber \& L. Mitchell (Eds.). Early childhood education for a democratic society: Conference proceedings (pp. 17-25). Wellington, New Zealand: Council for Educational Research.

Penetito, W. (2002). Research and context for a theory of Māori schooling. McGill Journal of Education, 37(1), 89-109.

Rosebery, A., McIntyre, E., \& Gonzalez, N. (2001). Connecting students' cultures to instruction. In E. McIntyre, A. Rosebery \& N. Gonzalez (Eds.), Classroom diversity: Connecting curriculum to students' lives (pp. 1-13). Portsmouth, NH: Heinemann.

Smythe S., \& Toohey, K. (2009). Investigating sociohistorical contexts and practices through a community scan: A Canadian Punjabi-Sikh example. Language and Education, 23(1), 37-57.

Spindler, G. Spindler, L. (1983). Review essay: the "case studies in education and culture: from cradle to grave". Anthropology and Education Quarterly, 14(2), 73-80.

Tangaere, A. (1997). Maori human development learning theory. In P. Te Whaiti, M. McCarthy, \& A. Durie (Eds.), Mai I Rangiatea Maori wellbeing 
and development, (pp. 46-59). Auckland, New Zealand: Auckland University Press.

U.S. Department of Education, National Center for Education Statistics. (2003). Status and trends in the education of Hispanics (NCES 2003-008). Washington, DC: Author.

U.S. Department of Education. (2001). No Child Left Behind Act. Washington, DC: Author. Retrieved on 01 August 2011 from: http://www2.ed.gov/policy/elsec/leg/esea02/107-110.pdf

Upadhyay, B. R. (2005). Using students' lived experiences in an urban science classroom: An elementary school teacher's thinking. Science Education, 90(1), 94-110.

Upadhyay, B. R. (2009). Teaching science for empowerment in an urban classroom: A case study of a Hmong teacher. Equity and Excellence in Education, 42(2), 217-232.

Valencia, R. R. (2010). Dismantling contemporary deficit thinking: Educational thought and practice. New York: Routledge.

Valenzuela, A. (1999). Subtractive schooling: U.S.-Mexican youth and the politics of caring. Albany: SUNY Press.

Varelas, M., \& Pappas, C. C. (2006). Intertextuality in read-alouds of integrated science-literacy units in urban primary classrooms: Opportunities for the development of thought and language. Cognition and Instruction, 24(2), 211-259.

Velez-Ibanez, C. G. (1988). Networks of exchange among Mexicans in the U.S. and Mexico: Local level mediating responses to national and international transformations. Urban Anthropology, 17(1), 27-51.

Vygotsky, L. (1978). Mind in society. Cambridge, MA: Harvard University Press.

Walker, R. (1973). Biculturalism in education. In D. Bray \& C. Hill (Eds.), Polynesian and Pākehā in New Zealand education (Vol. 1). (pp. 110-112). Auckland: Heinemann.

Wallace, J. M. Jr., Goodkind, S., Wallace, C. M., \& Bachman, J. G. (2008). Racial, ethnic and gender differences in school discipline among U.S. high school students: 1991-2005. Negro Educational Review, 59, 47-62.

Wink, J., \& Putney, L. (2002). A vision of Vygotsky. Boston, MA: Allyn \& Bacon.

Zipin, L. (2009). Dark funds of knowledge, deep funds of pedagogy: Exploring boundaries between lifeworlds and schools. Discourse: Studies in the Cultural Politics of Education, 30(3), 317-331. 


\section{The author}

Linda Hogg is a Pākehā lecturer in the School of Educational Psychology and Pedagogy in the Faculty of Education, Victoria University of Wellington, New Zealand. She is currently completing her doctorate, which explores the applicability of the funds of knowledge concept in New Zealand secondary schools. Linda has a background in teaching in Māori and Pasifika communities, in both New Zealand and the Cook Islands. Her research relates to her interest in social justice issues, including funds of knowledge, culturally responsive pedagogy, and collaborative methodologies.

Email: linda.hogg@vuw.ac.nz 